University of Louisville

ThinkIR: The University of Louisville's Institutional Repository

Electronic Theses and Dissertations

$2-1945$

\title{
The reaction of ethylcellulose with fatty acid and its application to the varnish industry : Il. ethylcellulose in pencil lacquers.
}

\author{
Albert L. Kimmel \\ University of Louisville
}

Follow this and additional works at: https://ir.library.louisville.edu/etd

Part of the Chemical Engineering Commons

\section{Recommended Citation}

Kimmel, Albert L., "The reaction of ethylcellulose with fatty acid and its application to the varnish industry : II. ethylcellulose in pencil lacquers." (1945). Electronic Theses and Dissertations. Paper 1989.

https://doi.org/10.18297/etd/1989

This Master's Thesis is brought to you for free and open access by ThinkIR: The University of Louisville's Institutional Repository. It has been accepted for inclusion in Electronic Theses and Dissertations by an authorized administrator of ThinkIR: The University of Louisville's Institutional Repository. This title appears here courtesy of the author, who has retained all other copyrights. For more information, please contact thinkir@louisville.edu. 
UNIVERSITY OF LOUISVILLE

I. THE REACTION OF ETHYLCELLULOSE WITH FATTY ACID AND ITS APPLICATION TO THE VARNISH INDUSTRY

II. ETHYLCELLULOSE IN PENCIL LACQUERS

\author{
A Thesis \\ Submitted to the faoulty \\ of the Graduate School \\ of the University of Loulsville \\ In Partial Fulfillment \\ of the Requirements \\ for the Degreo of \\ MASTER OF CHEMICAL ENGINEERING
}

Department of Chemlcal Engineering

Albert $L_{\pi}$ KImmeI

1945 
I. THE REACTION OF ETHYLCELLULOSE WITH FATTY ACID AND ITS APPLICATION TO THE VARNISH INDUSTRY

II. ETHYLCELLULOSE IN PENCIL LACQUERS

Albert L. Kimmel

Approved by Examining Committe日:

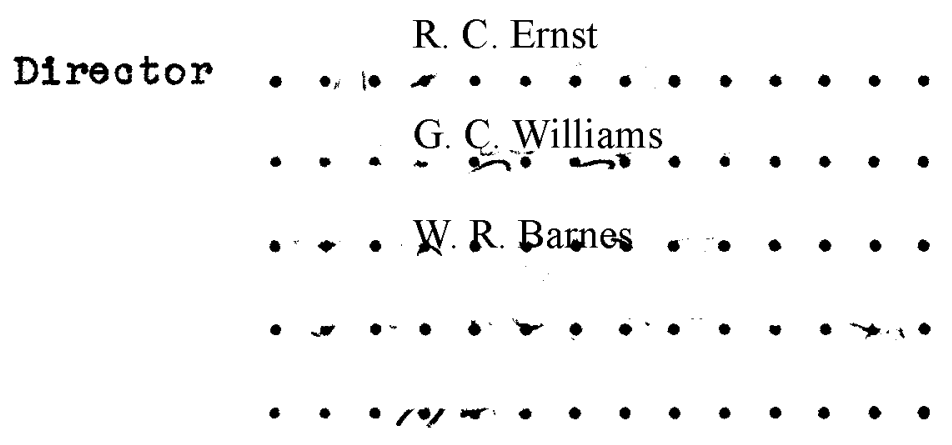

February 24, 1945 
TABLE OF CONTENTS

Page

Aoknowledgment.............................111

Abstract................................ 1v

Part I THE REACTION OF ETHYLCELLULOSE WITH FATTY ACID AND ITS APPIICATION TO THE VARNISH INDUSTRY

LIst of Tables............................. vil

List of Figures............................ vii1

Introduction.............................. 1

Historlcal............................... 2

Theoretical............................... 3

Experimental.............................. 8

Apparatus................................. 8

Materials.................................. 9

Experimental Mothods.......................... 9

Analytical Methods........................... 10

Data and Results........................... 12

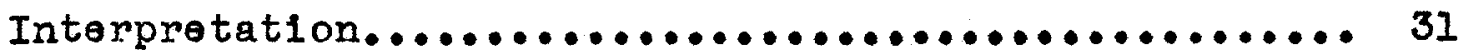

Conclusions................................ 33

Literature cited.............................. 34 
TABLE OF CONTENTS (CONCLUDED)

Part II ETHYLCELLULOSE IN PENCIL LACQUERS

List of Tables............................ 36

Introduction.............................. 37

H1storical................................. 38

Theoretioal............................... 39

Raw Materials............................... 40

Procedure.................................. 41

Methods of Testing.......................... 43

Results.................................... 44

Conclusions................................ 49

Reoommendations............................. 49

Aoknowledgment............................ 50

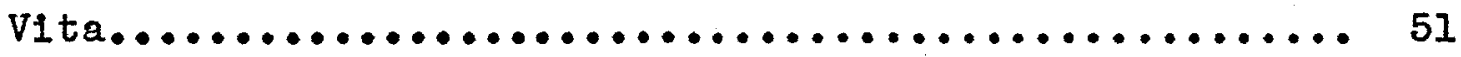




\section{ACKNOWLEDGMENT}

The Author wishes to express his sincerest approolation for the kind assistance and helpful guidanoe of Dr. R.C. Ernst who directed this research. 
REACTIONS OF ETHYLCELLULOSE WITH FATTY ACIDS.

Ethylcellulose was refluxed with stearic, 0le1c, Iinseed Fatty acids, and a noutral mineral 011 in the presence of a solvent. The products reoovered were analyzed to determine if any possible reaction had taken place. Conditions for the reaction were carried out so that the temperatures obtained could be in the near range of varnish oooking, that is betwoon $375^{\circ}$ and $500^{\circ} \mathrm{C}$. The solvents used were diethylbenzene, bolling point $180^{\circ} \mathrm{C}$. and tetralin, bolling point $208^{\circ} \mathrm{C}$. In each case approximate stoichiometric proportions of the fatty aoids and ethylcellulose were used. These were refluxed to a senstblo minimum visoosity of solution.

The analysis of the product showed that reaction took place at the hydroxyl groups, the ethoxy groups and also at the oxygen bridge. There was also aoid formed due to the breakdown of the ethylcellulose moleoulo.

The amount of acid reacted at the various groups in the ethylcellulose molecule, as mentioned above, and the amount of acid product of deomposition, serm to depend on the type of acid used and its reactive power. 


\section{ETHYLCELLULOSE IN PENCIL LACQUERS}

Ethyloellulose was used in a number of standard pencil laoquer formulas, totally replaoing the nitrocellulose and very good results were obtained. In all oases the plastiolzers and resin content were reduced between 30 and $50 \%$ from the amount used in the normal nitrocellulose formula. Pencils were coated in a standard penoll coating machine and were subjected to the tests of tack-free time, hardness, brittleness and aging. These laoquers showed that more cellulose and less plasticizers could be used in formulations and that very successful products can be obtained. 
v1

PART I

THE REACTION OF ETHYLCELLULOSE

WITH FATTY ACID AND ITS

APPLICATION TO THE VARNISH INDUSTRY 
IIST OF TABLES

Table

Page

I Welght Composition of Solutions............13

II Conditions and Physical Data on Reflux Sol-

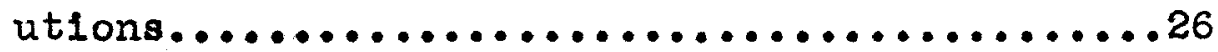

III Chomical Data on Solutions...............29

IV Acid Balance on the Products of Refluxing.....30

V Peroent Reaction at the Various Groups in the

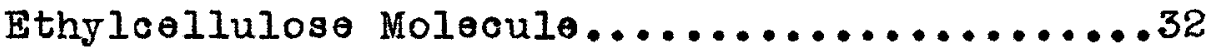


LIST OF FIGURES

Figure Page

1 Accepted Structure of Cellulose and Ethyl- 4 cellulose Moleoules.

2 Cooking Curve of an Ethylcellulose Modified

Varn1sh............................. 7

3 Apparatus for Refluxing Solutions............ 16

4 Viscosity Reduction Curve and Acid Number Curve. 17 (Stearic acid, ethylcellulose, tetralin sol.)

5 Visoosity Reduction Curvo................... 18 (Olelo acld, diethylbenzene, ethyloeliulose sol)

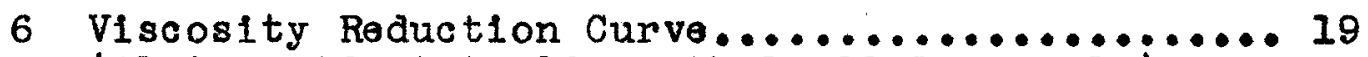
(Olelc acid, tetralin, ethyloeilulose sol.)

7 Viscosity Reduction Curve...................20 (Mineral 011, diethylbenzene, ethylcelilulose sol.)

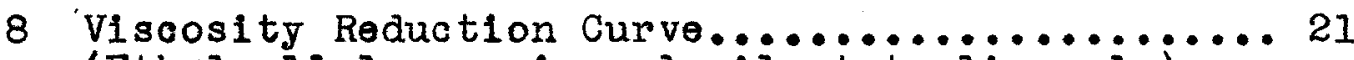
(Ethylcellulose, mineral oil, tetralin sol.)

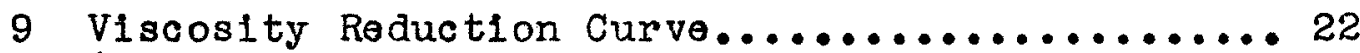
(Ethylcollulose, Inseod fatty acid, diethylbenzene sol.)

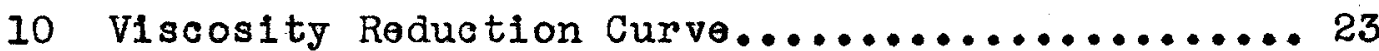
(Linse日d fatty acid, tetralin, ethyloeliulose sol.)

11 Viscosity Reduction Curve.................. 24 (Ethyloeliulose, diethylbenzene sol.)

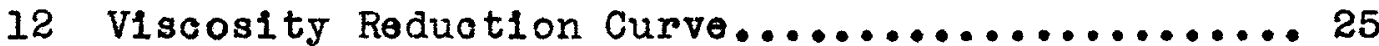
(Ethylcollulose, tetralin sol.) 


\section{INTRODUCTION}

The industrial application of ethylcellulose to the varnish industry has long been contemplated and successful varnishes have been made using this material. It has definitely boen established that drying propertios and structure of the film can be improved by the incorporating of ethylcellulose. Ethylcollulose in varnishes tends to produce a semi-gloss or dull film, however this is not an undesirable property since these types of varnishes are used extensively in the furniture and woodwork Industry.

Varnishes are prepared in the conventional manner by cooking natural or synthetic resins and drying oils according to the usual schedule and the ethylcellulose is added as the batch cools. For best results the addition is made at $450^{\circ} \mathrm{F}$.

This investigation has been made to try to determine whether ethylcollulose reacts chemically with the functional groups of the polymerized resin oll solutions or if it is merely a physioal dispersion. 


\section{HISTORICAL}

In recent years a certain amount of success has been obtained by using ethylcellulose in varnish formulation. Ethylcellulose, when incorporated in oleo-resinous varnishes, improves the drying time and the initial paint resistance of the varnish film. It improves the through dry and minimizes wrinkling. It also decreases penetrating and produces a tougher dry film than when straight heat body olls are used.

Previous work of reacting ethylcellulose with fatty acids has been done by Worden (9) and Hunter ( 7 ), however thelr work was done at low temperatures. Hulette (6) reacted ethylcellulose with steario acid at the same temperatures which are reported in this thesis with a reasonable amount of sucoess. However some possibilities were overlooked due to the fact that all products of reaction were not collected and only one acid was used.

All other work except that of Hulette were made by using an ester of stearic aoid rather than the pure acid, therefore, the results are not applicable to the varnish industry. 


\section{THEORETICAL}

Ethylcellulose is a product of the double displacement reaction between alkali-cellulose and ethyl chloride under certain specific conditions. According to the method described by S. Uschakov and I. Schneer (8) the most favorable conditions for formation are 6 moles of ethyl chloride and 1 of alkal1-cellulose heated to $120-130^{\circ} \mathrm{C}$. for 18 hours and then followed by meroerization with $50 \% \mathrm{NaOH}$ solution.

Commercially, we may obtain ethylcellulose with ethoxy contents ranging from $41 \%$ to $49.5 \%$ ethoxy which is equivalent to a mole ratio of 2.5 ethoxy groups per glucolse unit. Accepted structures of cellulose and ethyloellulose are shown in fig.(1). Ethylcellulose may also be obtained in a variety of visoosities depending on the manner in which the original cellulose was treated.

There are four types of reactions which are possible when ethylcellulose is reacted with a fatty acid:

(1) Esterification with the available hydroxyl groups.

(2) Reaction with the ethoxy group.

(3) Cleavage at the oxygen bridge.

(4) Reaction at the point of cleavage at the oxygen bridge.

If reaction (I) takes place we could expect an amount of water equivalent to the amount of acid reacted. 


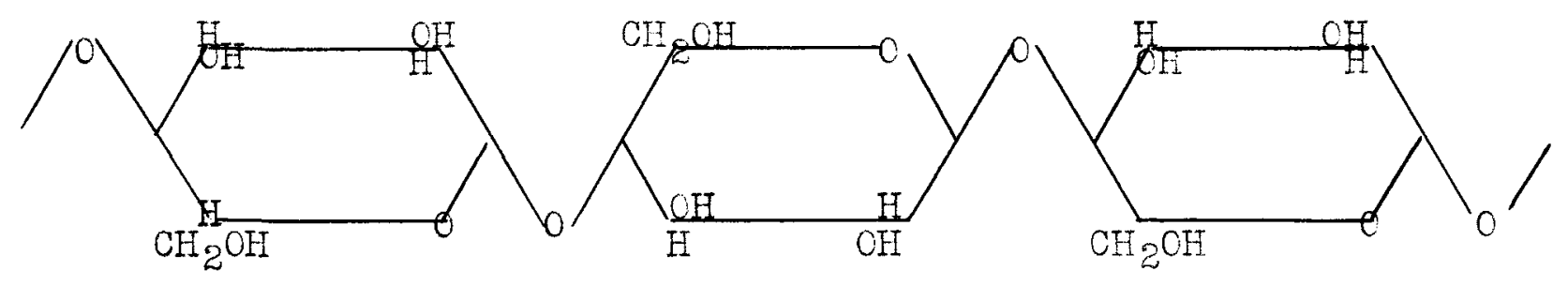

STRUCTURAL FORROULA PCR FITE CHIUTCSR IOITCUIT

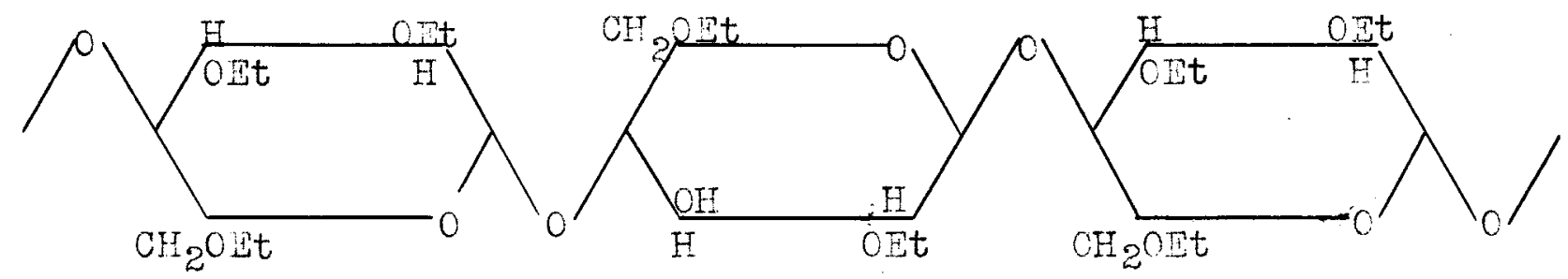

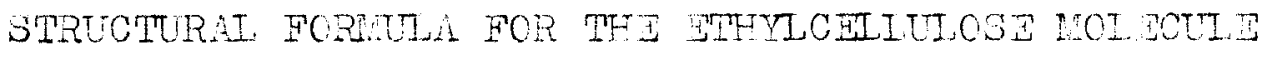

Fig. 1 
If reaction (2) takes place we would expect ethyl alcohol to be liberated. If reaction (3) takes place all we could expect would be a decrease in viscosity of tho solution. With reaction (4) we would obtain a decrease in viscosity and one equivalent of water for every 2 moles of acid reacted, assuming a monobasic acid is used in the reaction.

Ethylcellulose has been reacted with stearic acid as desoribed by Worden (9) in British patent 270,347 by reacting one part of ethylcellulose and 7 parts of stearlc acid for 6 hours at $150^{\circ} \mathrm{C}$. Hunter (7) describes the preparation of ethylcellulose stearates by reacting stearyl ohloride and ethyl cellulose in pyradine solutions. The resulting product showed a slight change in viscosity of the unmodified cellulose.

Berl and Schupp (I) report that diethylcellulose is broken down and ethyl groups split off by acetolysis. This type of reaction would be indioated by a deorease in the ethoxy content of the final product and also in the saponification values.

According to Doree (3) cellulose is not affected by heat up to a temperature of $140^{\circ} \mathrm{C}$. even after prolonged heating. Increases in temperature however decrease the viscosity on prolonged heating. Furthormore, Birtwell, clebbins and Geake (2) reacted cellulose with acids at 
various conditions and showed that a definite relationship existed between loss of tensile strength and loss of viscosity of the cellulose.

The procedure used in making an ethylcellulose modifled varnish is illustrated by the curve fig.(2). Since the temperature of reaction is about $450^{\circ} \mathrm{F}$. then the reactions must be carried out in this range. This temperature is above the decomposition temperature of the ethylcellulose so it is expected that products of decomposition will be formed as well as a decrease in viscosity. The decrease in viscosity is very well shown by Hulette (6) who measures the viscosity change as his refluxing progressed.

If any reaction is taking place it would be indicated by the acid number of the solution as the refluxing progressed. It would also be indicated if the products of decomposition were acid in nature. 


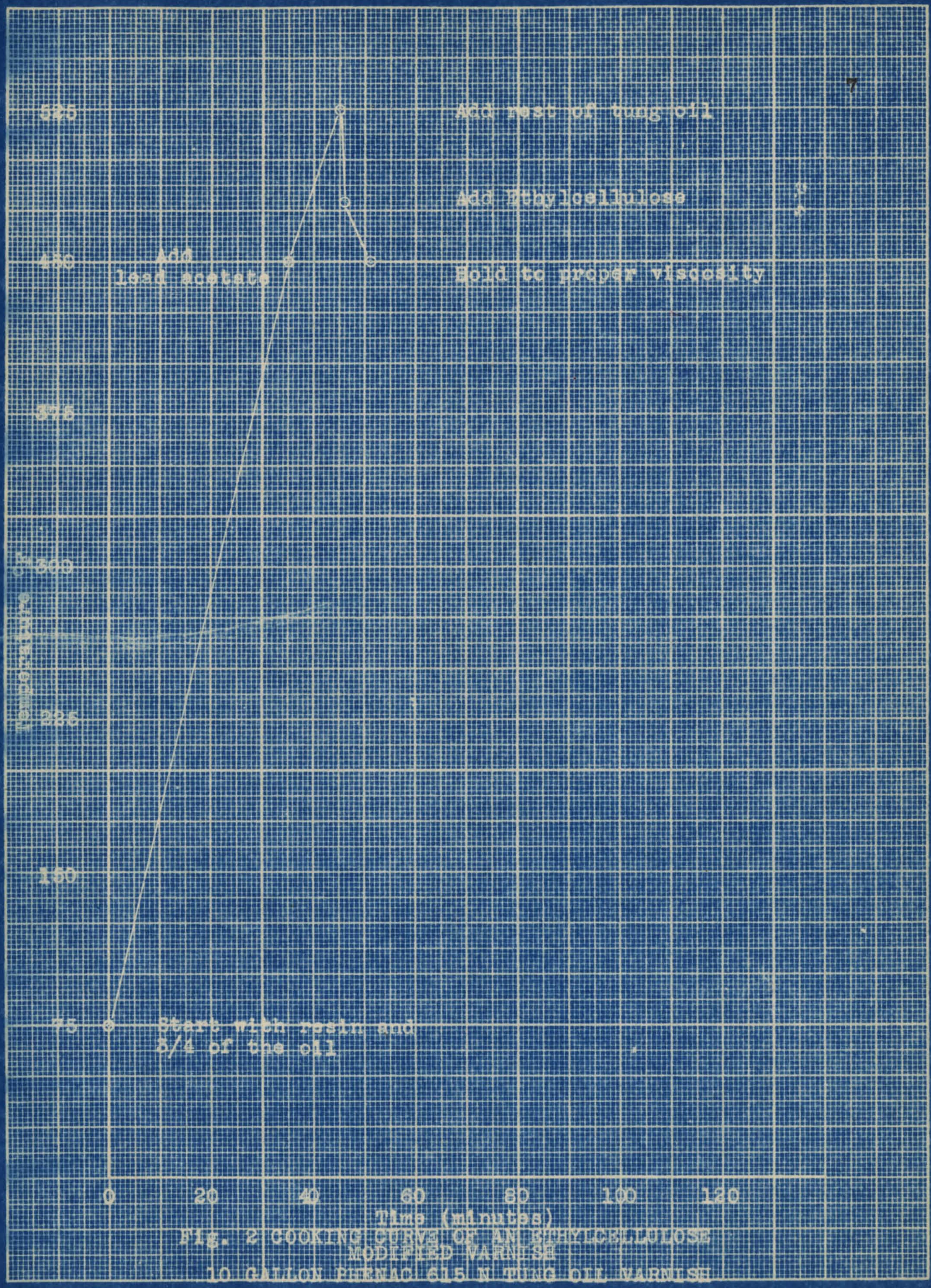


EXPERIMENTAL

The ethylcellulose was refluxed with a number of fatty acids in the prosence of solvents which had definite bolling points. As the refluxing proceoded, viscositios were determined. In all cases the reaction was carried to a minimum viscosity. It was assumed that the minimum was reached when there was no further change during a 2-hour poriod of time. In one case acid numbers as well as viscositios were mun on the refluxing mixture.

\section{APPARATUS}

Apparatus used for the refluxing was a 2 liter, 3 nooked flask fitted with a reflux condenser; a themometer woIl and a built-in viscosity tube. The condenser was fitted with a water trap attaohment making possible direct reading in cos. All connections to the flask were of ground glass roducing losses to a minimum. When it was desired to collect all the products of docomposition, a draw-off tube and a thermometar wore fitted in the top of the condenser and to this tube was connected $2 \mathrm{U}$-tubes, one immersed in an ice bath to collect any aloohol which might be. given off. The other was filled with soda lime to absorb any liberated carbon dioxide. Heat was suppliod to the 3 nocked flask through a medium of wood's metal which was kept at a molten state by an electric heater. 


\section{MATTERIAL}

The following materials were used in this investigation:

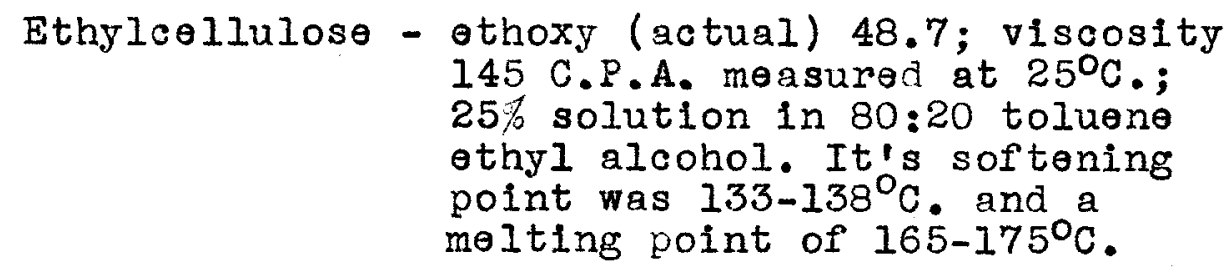

Stearic acid - C.P. grado

Ololo acid - C.P. grado

Linserd fatty acids - commorcial grade

Mineral oll - S.A.C. 30 (Gulf Refinery).

Diethylbenzene - redistilled.

Tetralin - redistilled and dried over $\mathrm{CaCl}_{2}$.

Carbon dioxide gas - dry commercial grade.

\section{EXPERIMENTAL METHODS}

Solutions containing stolchiometric proportions of ethylcellulose and the fatty acids were made with each of the solvents and refluxed to a minimum viscosity. In the case of the mineral oil, and linserd fatty aoids only approximate stolchiometric proportions could be used. More oonsistant results were obtained with the steario acid, therefore chock runs were made collecting Carbon dioxide and alcohol evolved. Solutions containing solvent and ethylcellulose, and solvent and fatty aciàs were also refluxed so that any decomposition, change in viscosity, change in acidity, and water present could be detected. Table (I) 
shows the welght composition of all solutions refluxed and the materials in the solution.

The ethylcellulose, fatty acid and solvent were heated in a wator bath until a clear solution was obtained. These resulting solutions were then refluxed at their boiling point until a minimum viscosity was reached. The final viscosity was then measured at $25^{\circ} \mathrm{C}$. Other viscosities measured during the prooess of refluxing were at the reflux temperature and were recorded in seconds.

In all cases where we were not interested in determining the amount of Carbon dioxide gas given off by the roaction an atmosphere of this gas was maintained over the reacting mixture to minimize oxidation. The Carbon dioxide was admitted to the flask through the viscosity pipette. This also serred to agltate the solutions.

When we measured the carbon dioxide evolved, the flask was beated open until the solvent vapor drove out the alr. The system was then closed and the high temperature kept the air from reentering the flask.

\section{ANALYTICAL METHODS}

In order to analyze the resulting product it was necessary to remove the high bolling solvent. This was accomplished by two mothods. First by steam distillation. This procedure left a mixture of ethylcellulose and stoaria acid whioh was redissolved in acetone and 
preolpitated by pouring in an excess of water. This precipitate was filtered and dried to a constant weight in an atmosphere oven at $110^{\circ} \mathrm{C}$. The second method consisted of pourIng the reflux mixture in an excess of V.M.P. naptha and boiling the precipitate in four successive volumes of this solvent. This yielded a product free from any excess fatty acid. Both methods were used and will be indioated in the data. The resulting samples were then analyzed for ethoxy content, acid number, and saponification number. The problem of running the acid number and saponification values, due to the dark color of the solution, was solved in using the methods of Gardner (5) and Hulette (6). For the saponffication value, the ethyl aloohol was added in the form of $0.5 \mathrm{~N}$ alcoholio $\mathrm{NaOH}$, so as not to disturb the solvent combination. The solutions were refluxed one hour and back titrated with $0.5 \mathrm{~N} \mathrm{HCl}$. The indicator used was thymol-blue. The color change was from a blue-green to a yellow. 


\section{DATA AND RESULTS}

The solvents used were first double distilled to free them from any water present or any dissolved foreign matter. During the distillation the first $50 \mathrm{cc}$. to come off were discarded and the distillation continued until there remained about $100 \mathrm{cc}$. In the distilling flask. The distilled solvents, about two liters, each were stored in large glass bottles containing about $25 \mathrm{gms}$. of calclum chlorido. After about three days specific gravity and refracting index was run on the solvents and there was shown a high degres of purity.

The following is the procedure used for operations. Ethylcellulose, solvent, and fatty aclds were weighed into the 3 neoked flask. The flask was heated on a water bath until homogeneous solutions resulted. The condenser, thermometer, and viscosity pipette were then connected and the flask placed in the wood's metal bath. A precision, adjustableelectric heater supplied the heat to the system. The first viscosity was taken just as the solution reached the boiling point and every 15 minutes thereafter. In order to check the teohnique and methods involved, the results obtained from the systens ethylcellulose, stearic acid, tetra1 in, and ethylcollulose tetralin (runs $I$ and 10) were checked with the results of Hulette (6) who conducted a similer project. All materials used were checked for changes 
TABLE I

COMPOSITION CF SCLUTIONS FOR REFLUXING

\begin{tabular}{|c|c|c|c|c|}
\hline $\begin{array}{l}\text { Sol. } \\
\text { No. }\end{array}$ & $\begin{array}{l}\text { Fatty } \\
\text { Acid }\end{array}$ & Solvent & $\begin{array}{l}\text { Grams of } \\
\text { Fatty Acid }\end{array}$ & $\begin{array}{l}\text { Grams Ethyl- } \\
\operatorname{collulose}\end{array}$ \\
\hline 1. & Stoaric & Tetralin & 36.0 & 60.0 \\
\hline 2 & Stearic & Tetralin & 36.0 & 60.0 \\
\hline 3. & 01010 & D.E.B.** & 38.2 & 60.0 \\
\hline 4 & oleio & Tetralin & 38.2 & 60.0 \\
\hline 5. & Mineral ofl & D.E.B. & 36.0 & 60.0 \\
\hline 6. & Mineral oil & Tetralin & 36.0 & 60.0 \\
\hline 7. & Linse日d F.A.* & D.E.B. & 36.0 & 60.0 \\
\hline 8. & Linse日d F.A. & Tetralin & 36.0 & 60.0 \\
\hline 9. & --- & $D \cdot E \cdot B$. & --- & 60.0 \\
\hline 10. & --- & Tetralin & --- & 60.0 \\
\hline 11. & $-\cdots$ & Totralin & ---- & 60.0 \\
\hline 12 & Stearic & Tetralin & 36.0 & --- \\
\hline 13. & 01010 & D.E.B. & 38.2 & --- \\
\hline 14. & 01010 & Tetralin & 38.2 & --- \\
\hline 15. & Linseed F.A. & D.E.B. & 36.0 & --- \\
\hline 16. & Inseed F.A. & Totralin & 36.0 & --- \\
\hline 17. & Mineral 011 & D.E.B. & 36.0 & --- \\
\hline 18. & Minoral oil & Tetralin & 36.0 & --- \\
\hline
\end{tabular}

NOTE: 600 grams of solvent were used in preparing all solutions. 
in the ethoxy content, water given off and acidity of the ethylcellulose when no acid was present, changes in physical properties, water given off and acidity of the solvents and fatty acids. The weight composition of the solutions are given in Table I.

The refluxing operation was carried on in the apparatus shown in fig. (3) and the graphs figs. (4-12) show the changes In viscosity during the operations; viscosities were measured at the reflux temperature by neans of a viscosity pipette inside the reaction vessel. The refluxing was carried on one hour after a sensibie minimum viscosity had been reached. A study in the change of the acid condition was also made on sample (2) and this 18 shown in graph fig. (4). This was accomplished by withdrawing a small portion of the solution ( 3 grams) and titrating in the usual manner to obtain the acid number.

A summary of the roflux conditions and the physical data on the final solutions are given in Table II. This includes the reflux temperature, time of roflux, final viscosity at $20^{\circ} \mathrm{C}$, the water collected and the color of the solution.

The final acid number of the solutions were then mu, and the product steam distilled to remove the high boiling solvents. The solld products obtalned were then dissolved in acotone, reprecipitated by pouring into an oxcess of distilled water, filtered and then dried to a constant welght. 
In an atmospheric oven. Since a portion of the acids were retained in the steam distilled product, it was again necessary to run the acid number in order that the true ethoxy content could be calculated. 


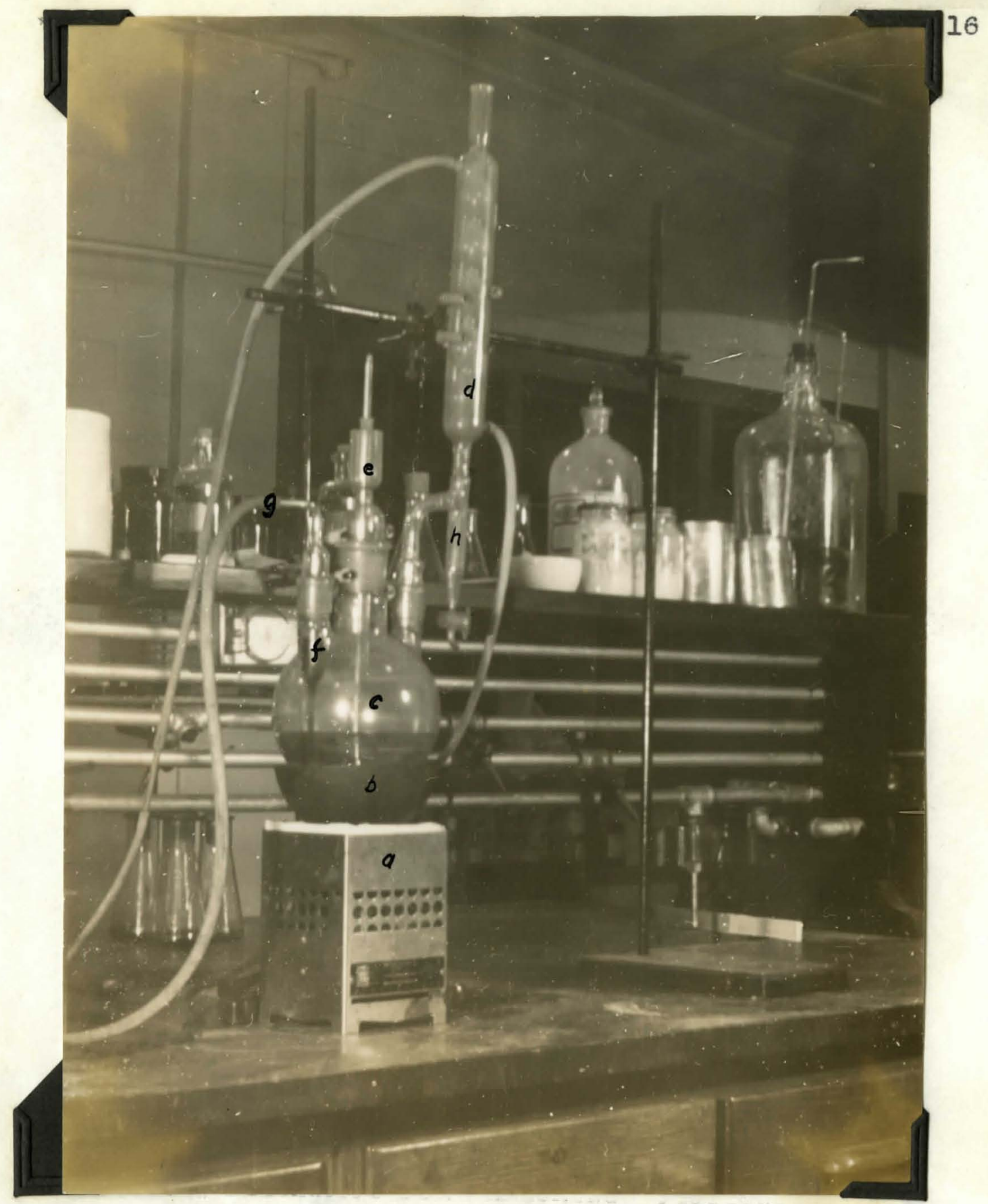

F1g. 3 Apparatus for Refluxing Solutions

a. Electric Heater

b. Wood's Metal Bath

c. Three necked Reaction flask

d. Condenser e. Thermometer and thermometer well

f. Viscosity pipette

g. $\mathrm{CO}_{2}$ inlet

h. Water trap 


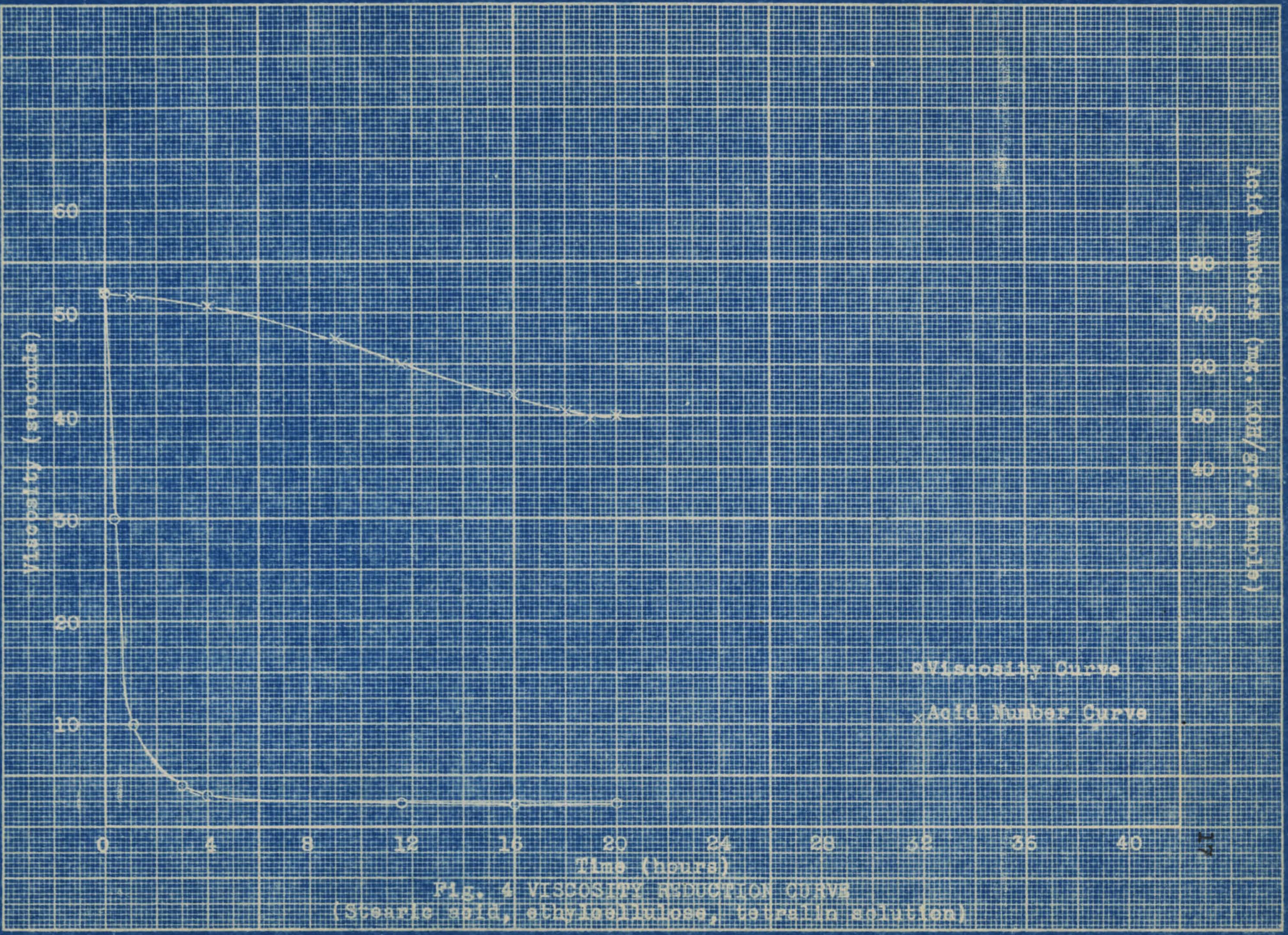




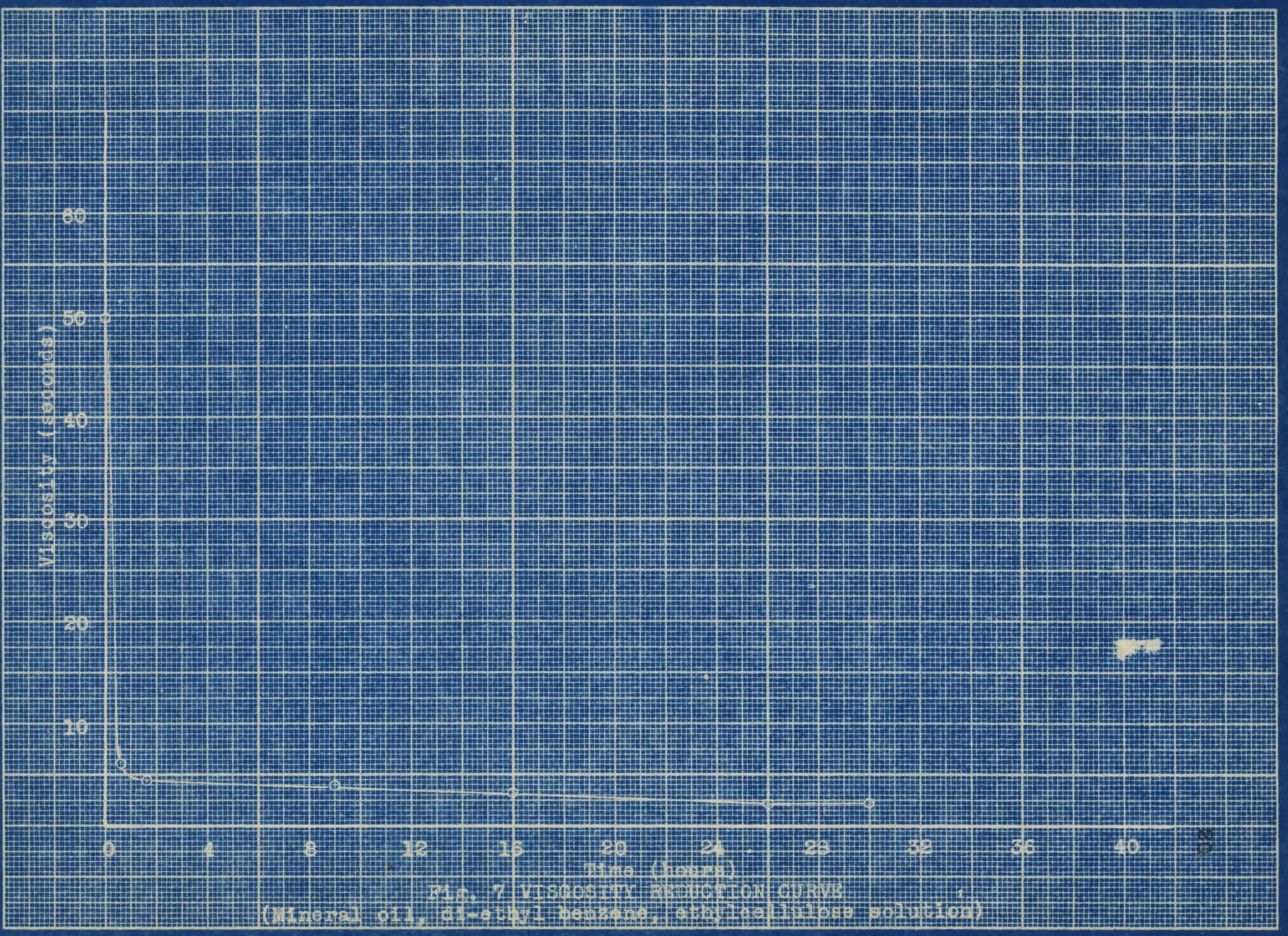




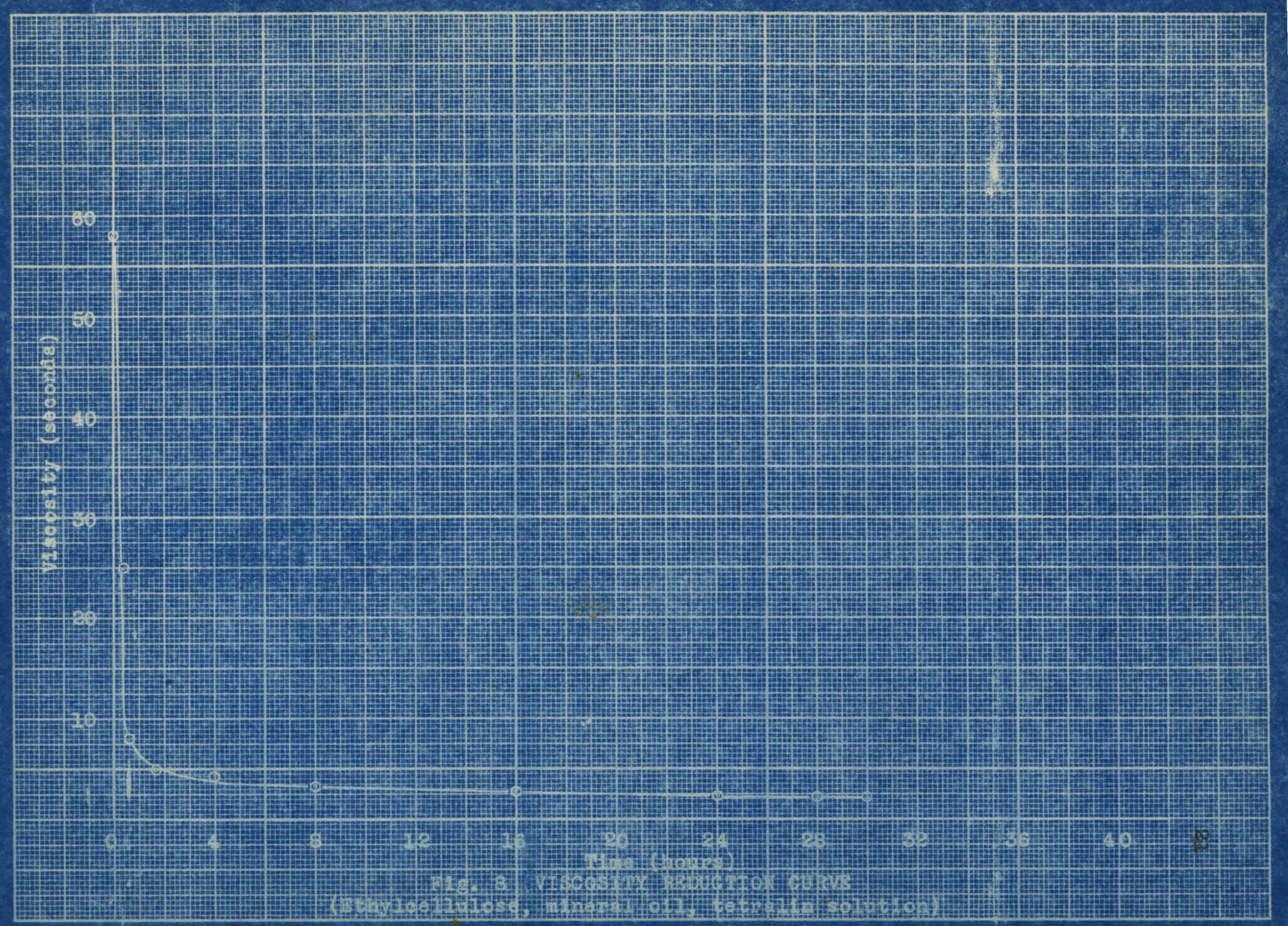




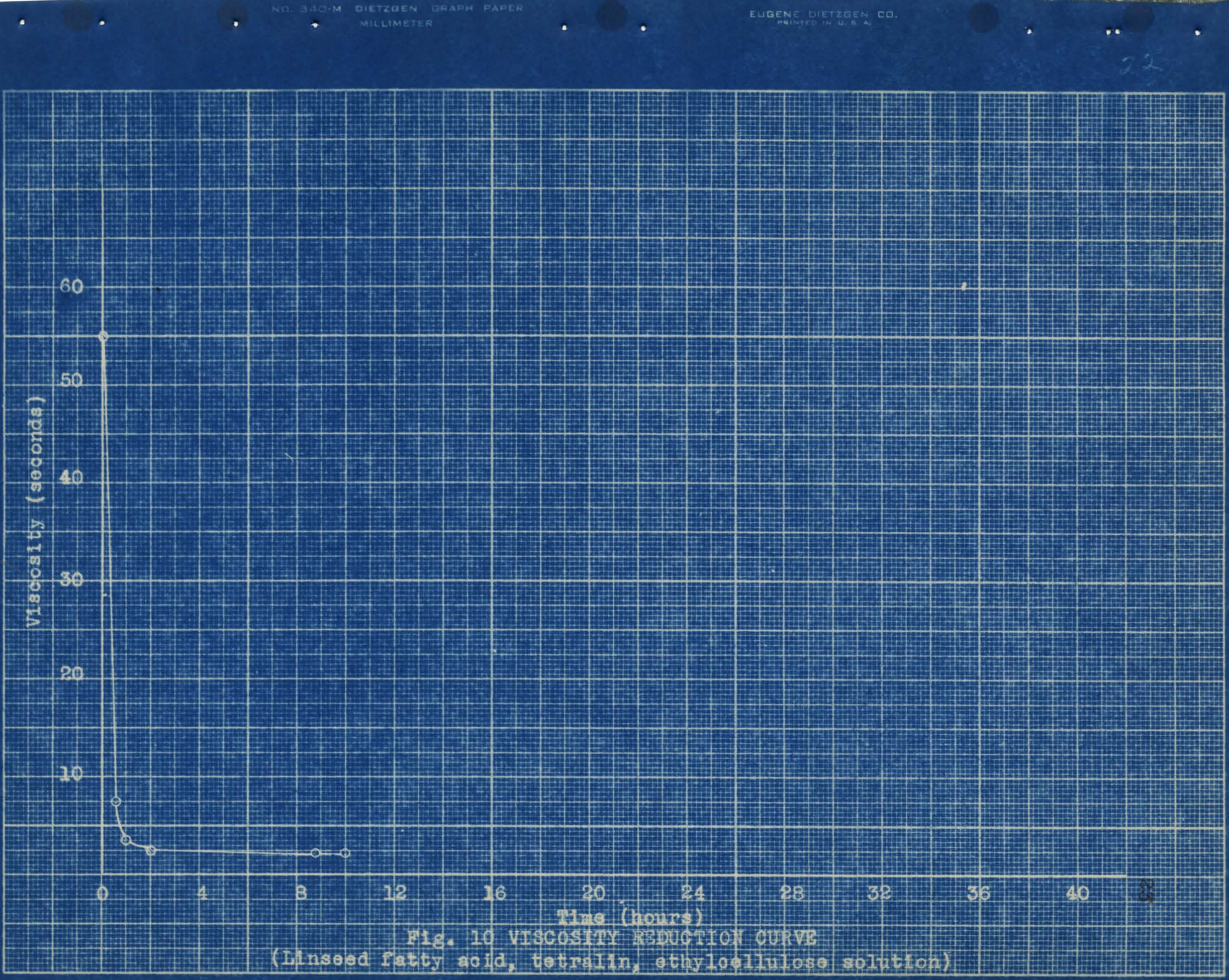




\section{$\therefore \quad$




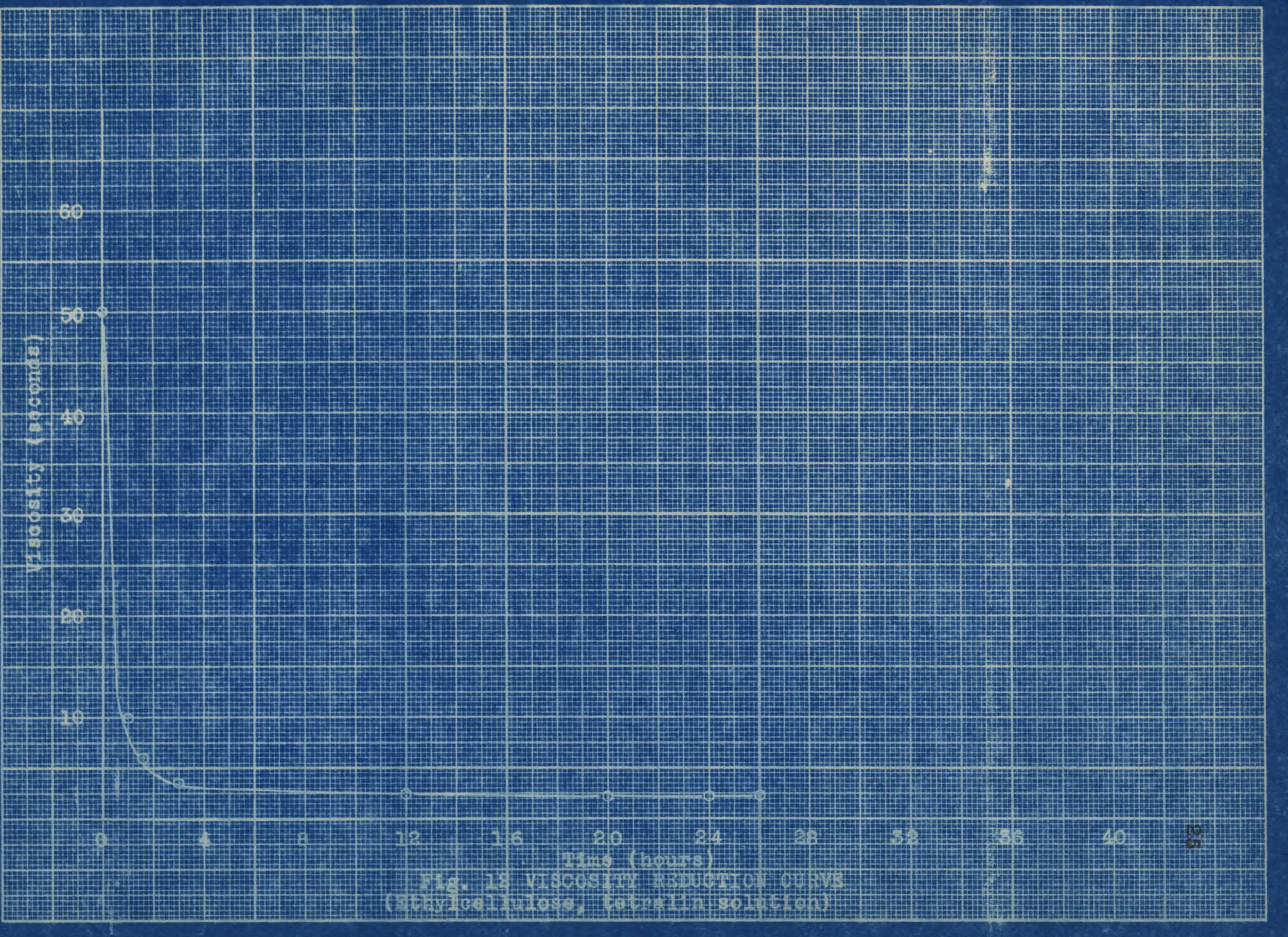




\section{TABLE II}

\section{CONDITIONS AND PHYSICAL DATA ON REFLUX SOLUTIONS}

\begin{tabular}{|c|c|c|c|c|c|}
\hline $\begin{array}{l}\text { Sol. } \\
\text { No. }\end{array}$ & $\begin{array}{l}\text { Temp. } \\
\text { Degrees C. }\end{array}$ & $\begin{array}{l}\text { Reflux } \\
\text { Time hrs. }\end{array}$ & $\begin{array}{l}\text { Viscosity } \\
\text { Final min. }\end{array}$ & $\begin{array}{l}\text { Water in } \\
\text { co. }\end{array}$ & $\begin{array}{l}\text { Color of } \\
\text { Solution }\end{array}$ \\
\hline 1. & 208 & 12.50 & 9.00 & 1.50 & dark straw \\
\hline 2. & 208 & 13.00 & 9.08 & 1.55 & dark straw \\
\hline 3. & 180 & 30.00 & 12.00 & 1.11 & straw \\
\hline 4. & 208 & 8.91 & 8.00 & 2.11 & dark brown \\
\hline 5. & 180 & 30.00 & 6.70 & 0.05 & light straw \\
\hline 6. & 208 & 30.00 & 11.11 & 0.80 & straw \\
\hline 7 . & 180 & 14.00 & 15.00 & 1.30 & pale straw \\
\hline 8. & 208 & 9.75 & 13.00 & 1.90 & l1ght straw \\
\hline 9. & 180 & 56.00 & 12.00 & 0.50 & straw \\
\hline 10. & 208 & 40.00 & 9.00 & 0.90 & l1ght straw \\
\hline 11. & 208 & 40.00 & 9.00 & 0.90 & light straw \\
\hline 12. & 208 & 5.00 & ---- & --- & $-----\cdots$ \\
\hline 13. & 180 & 5.00 & ---- & --- & $-----\cdots$ \\
\hline 14. & 208 & 5.00 & ---- & --- & $---\infty \cdot--\infty$ \\
\hline 15. & 180 & 5.00 & ----- & --- & $----\infty---$ \\
\hline 16. & 208 & 5.00 & $-\cdots-n$ & --- & ------- \\
\hline 17. & 180 & 5.00 & ----- & $-\infty-\infty$ & $----\infty-\infty-\infty$ \\
\hline 18. & 208 & 5.00 & $-\cdots$ & -- & -------- \\
\hline
\end{tabular}


The chemical data taken on the refluxed solutions is given in Table III. This includes the water of esterification, the alcohol liberated (thooretical), calculated from the ethoxy, the acid number on the steam distilled product, and the peroent true ethoxy.

Table IV is an acid balance on the product containing infial acid content of the solution, free acid in the steam distilled product, total freo acid, freo and reacted acid, acid reacted at $\mathrm{OH}$ groups, acid reacted at the ethoxy, acid reacted at the oxygen bridge, acid formed by decomposition of the ethylcellulose and acid of decomposition due to acid present.

The total fres acid, and the freo and reacted acids wore calculated from the acid nuraber of the solution, and the saponification value respectively.

The acid roacted at the $\mathrm{OH}$ groups, was obtained from the water collected during the refluxing after it had beon corrected for the wator normally given off when no acid is present.

The acid reacted at the othoxy groups, is the acid equivalent of the difference between the Ethyl alcohol given off when the solutions of ehtylcellulose were refluxed with and without an acid present.

The acid reacted at the oxygen bridge is the difference between the total reacted acid, the acid reacted at the $\mathrm{OH}$ and ethoxy. 
The acid of decomposition was calculated from the total free and reacted acids, and the acid originally present in the solutions.

The acid of decomposition due to acid present is obtained from the total acid of decomposition in the solutions containing no aold. 


\section{TABLE III}

CHEMICAL DATA ON SOLUTIONS

\begin{tabular}{|c|c|c|c|c|c|c|c|}
\hline $\begin{array}{l}\dot{0} \\
\dot{a} \\
\dot{0} \\
\dot{0}\end{array}$ & 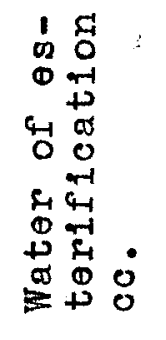 & 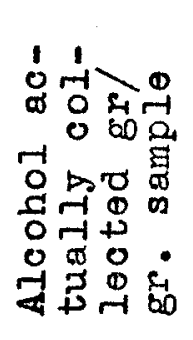 & 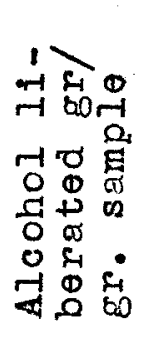 & 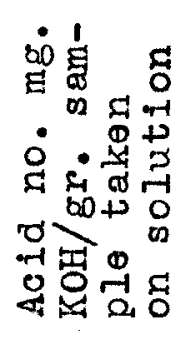 & 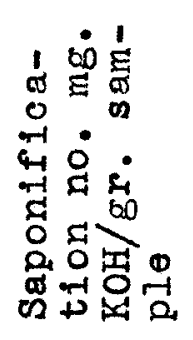 & 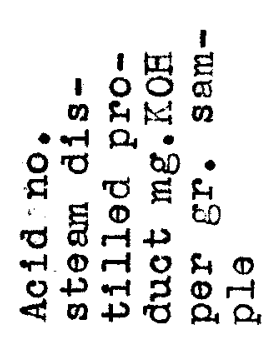 & 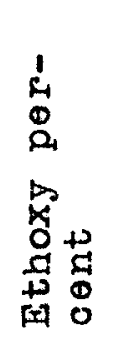 \\
\hline 1. & 0.400 & ----- & 1.640 & 49.50 & 76.80 & 49.0 & 42.2 \\
\hline 2 & 0.450 & 0.530 & 1.550 & 50.00 & 76.00 & --- & 43.5 \\
\hline 3. & 0.160 & ----- & 0.955 & 52.30 & 77.30 & 25.2 & 43.1 \\
\hline 4. & 0.260 & $--\cdots$ & 1.960 & 43.40 & 77.00 & 35.3 & 41.0 \\
\hline 5. & 0.000 & $\cdots$ & $-\ldots$ & 2.70 & 2.72 & $-\cdots$ & 45.4 \\
\hline 6. & 0.000 & ---- & ---- & 2.72 & 2.73 & --- & 45.0 \\
\hline 7. & 0.100 & & 0.626 & 52.80 & 64.40 & 15.6 & 44.2 \\
\hline 8. & 0.250 & ----- & 1.075 & 42.80 & 66.20 & 36.7 & 42.3 \\
\hline 9. & 0.000 & - & 0.713 & 0.93 & 0.940 & --- & 46.3 \\
\hline 10. & 0.000 & $---\infty$ & 0.865 & 1.18 & 1.230 & 45.8 & 45.8 \\
\hline 11. & 0.834 & 0.042 & 1.150 & 1.20 & 45.90 & --- & 45.9 \\
\hline
\end{tabular}


TABLE IV

ACID BALANCE ON THE PRODUCT OF REFLUXATION

\begin{tabular}{|c|c|c|c|c|c|c|c|c|c|}
\hline $\begin{array}{l}\dot{\circ} \\
\dot{z} \\
\dot{0} \\
0\end{array}$ & 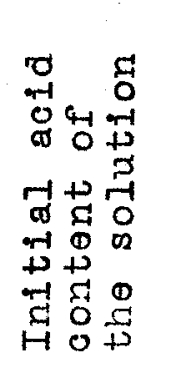 & 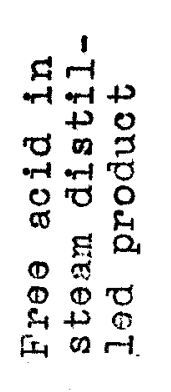 & 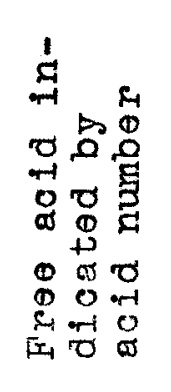 & 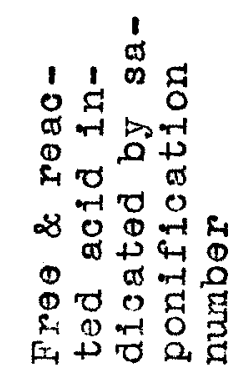 & 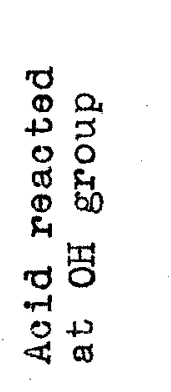 & 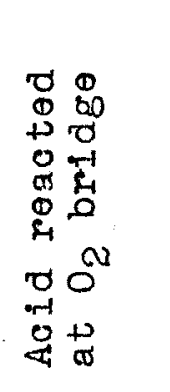 & 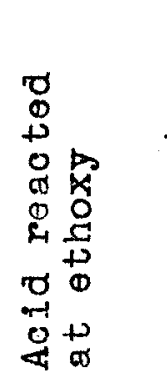 & 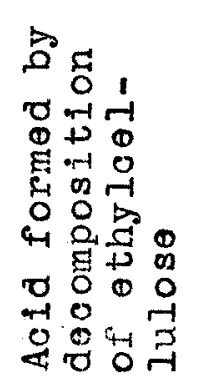 & $\begin{array}{l}0 \\
0 \\
0 \\
0\end{array}$ \\
\hline 1. & .3750 & --- & .2510 & .3815 & .0645 & .0156 & .0510 & .0064 & .0070 \\
\hline 2. & .3750 & --- & .2535 & .3850 & .0727 & .0080 & .0462 & .0062 & .0051 \\
\hline 3. & .3980 & .125 & .3081 & .4150 & .0262 & .0090 & .0654 & .0161 & .0100 \\
\hline 4. & .3980 & .190 & .2335 & .4141 & .0445 & .0120 & .1340 & .0107 & .0060 \\
\hline 5. & .3750 & .235 & .3780 & .3811 & $-\cdots$ & $-\cdots$ & $\cdots$ & .0047 & $-\cdots$ \\
\hline 6. & .3750 & .240 & .3811 & .3811 & --- & $-\cdots-$ & $\cdots-$ & .0061 & $-\cdots$ \\
\hline 7. & .3750 & .084 & .3144 & .3851 & .0190 & .0032 & .0474 & .0091 & .0026 \\
\hline 8. & .3750 & .205 & .2550 & .3891 & .0475 & .0054 & .0812 & .0141 & .0076 \\
\hline 9. & $-\cdots$ & $-\cdots$ & .0047 & $-\cdots-$ & $-\cdots$ & $\cdots-\cdots$ & $\cdots-$ & .0047 & $\cdots$ \\
\hline 10. & $-\cdots-$ & --- & .0060 & .0063 & $-\cdots$ & $\cdots-$ & ---- & .0063 & $\cdots-$ \\
\hline 11. & $-\cdots-$ & $\cdots$ & .0058 & .0061 & ---- & $\cdots$ & $\cdots--$ & .0061 & $\cdots-$ \\
\hline
\end{tabular}




\section{INTERPRETATION OF DATA}

The time required to reach minimum viscosity has been found by Hulette (6) to be an inverse function of the temperature. This is true, however, only when there is no acid present. The data definitely indicates that the properties of the acid present greatly influence the time required to reach.minimum visoosity.

A study of f1g. (4) Indicatos that the acidity of the solutions decrease due to reaction until decomposition of the cellulose begins, then the acidity curve begins to flatton and on prolonged hoating should gradually rise.

The color of the solutions in all cases darkened as the time of refluxing increased.

The acid balance Table IV indioates that we have reaction at all places and the percent reacted at the various places are given in Table V. The theoretical amount reacted at the $\mathrm{OH}$ groups would have given off 2.35 cc. of water (density 0.98 ) and In no case was this amount accounted for. If the acid had completely reacted with ethoxy groups we should have obtained 29.85 grams of ethyl alcohol, this also, was never obtained as shown in Table III, runs numbers 2 and 11. In conneotion with the above me may state that the amount of reaction of the various groups depends largely on the time of reaction, the acid present and the temperature of 


\section{TABLE V}

\section{PERCENT REACTION AT THE VARIOUS}

GROUPS IN THE ETHYLCELLULOSE MOLPCULE

\begin{tabular}{|c|c|c|c|c|}
\hline $\begin{array}{l}\text { Sol. } \\
\text { No. }\end{array}$ & $\begin{array}{l}\% \text { Reacted } \\
\text { at } \mathrm{OH}\end{array}$ & $\begin{array}{l}\% \text { Reacted } \\
\text { at Ethoxy }\end{array}$ & $\begin{array}{l}\text { \% Reacted at } \\
\text { Oxygen bridge }\end{array}$ & $\begin{array}{l}\% \text { Acid of } \\
\text { Decomposition* }\end{array}$ \\
\hline 1. & 17.20 & 13.60 & 4.51 & 1.84 \\
\hline 2. & 19.40 & 12.30 & 2.13 & 1.33 \\
\hline 3. & 6.57 & 16.40 & 2.26 & 2.40 \\
\hline 4. & 11.20 & 33.60 & 3.08 & 1.45 \\
\hline 5. & -- & $\ldots-$ & $-\ldots$ & $\cdots$ \\
\hline 6. & $\cdots$ & $\cdots$ & --- & $\cdots$ \\
\hline 7. & 5.10 & 12.25 & 0.86 & 0.67 \\
\hline 8. & 12.80 & 21.80 & 1.45 & 1.95 \\
\hline
\end{tabular}

* Percent acid of decomposition due to acid present, based on acid present. 


\section{CONCLUSIONS}

When Ethylcellulose is incorporated in a varnish it may be concluded that three things will take place. First, there will be ragction between the fres fatty acids in the oils and resins with the ethylcellulose at the oxygen bridge and cleavage points, at the hydroxyl groups, and the ethoxy groups. Second, the acidity of the varnish during, the incorporation period except on prolonged heating. Third, the decomposition of the ethylcellulose at the bodying temperature will darken the varnish depending on the time it is held. Since all these factors are a function of time and temperature they can be controlled. The fatty acids present in the olls and resins also would exert an influence on the three factors mentioned above. Studies of the different varnishes would be necessary to deternine the optimum conditions. 


\section{LITERATURE CITED}

1. Berl, E. and Sohupp, H., Cellulose Chomie, 10, 4I, (1929).

2. Birtwoll, Clibbens, and Geake, Journal of the Textile Institute, 17, 145, (1926).

3. Doree, "Methods of Cellulose Chemistry", p. 209, Chapman and Hall, London, (1933).

4. Dow Chemical Company, "Ethocel Handbook", Third Edition, pp. 75-80, Midland, Michigan, (1940).

5. Gardner, H.A., "Physical and Chemical Examination of Paints, Varnishes, Lacquers, and Colors", Eighth Edition, Washington, D.C., Institute of Palnt and Varnish Resoaroh, (1937).

6. Hulette, V.H., Jr., "Ethylcellulose Reaction In A Varnish", Section I, Thesis, University of Louisvilie, (194I).

7. Hunter, M.J., Private Communication to Hulette, March 20, 1941, Dow Chemical Company, Midland, Michigan.

8. Uschakov, S., and Schneer, I., Plastitschekie Mass1, 1, 17, (1931).

9. Worden, E.C., "Tochnology of Cellulose Ethers", First Edition, Vol. 1, pp. 1-80, Vol. 3, p. 1655, Milburn, N.J., Worden Laboratory and Library, (1933). 
PART II

ETHYLCELLULOSE IN PENCIL IAGQUERS 


\section{LIST OF TABLES}

Table

P.ge

I Standard N1trocellulose Lacquer Formula.....442

II Formulae For White Penoll Lacquers..........44

III Formula For Red Ponoll Laoquers...........45

IV Formulae For Yellow Penoll Laoquers........46

V Formula For Clear Top Coats...............47

VI $\quad$ Results of Tests.....................48 


\section{INTRODUCTION}

A survey of technical Iiterature reveals that there has be日n no previous attempts to use ethylcellulose in pencil lacquers. However the use of ethylcellulose in lacquer formulation has been studied for the past few years both by the industrial producers of the material and lacquer manufacturers. Successful formulations have been produced using ethylcellulose in lacquers for clear furniture finishes and a pigmented coating of various types.

These lac quers may be prepared in the conventional manner and the best methods found for incorporation of pigments is by grinding in a ball mill or a mbber mill.

The plastic properties of the ethylcellulose film are better than those of nitrocellulose therefore it has been possible in all previous investigations to use less plasticizers in the finishes.

This investigation is an attempt to use ethylcellulose in pencil lacquer formulation and to make a comparison of it with a standard nitrocellulose pencil finish. 


\section{HISTORICAL}

Lacquers have been used extensively for many years for their decorative propertios in coating pencils. Pencils receive anywhere from a minimum of three to a maxImum of fifteen coats of lacquer depending upon the price of the pencil and where it is to be sold. These laoquers may be olear, as in some of the cheaper pencils, or highly pigmented and a coat of clear on top for the more expensive varieties. They must dry in a few seconds and have a high viscosity that they may be applied with a coating machine.

From the physical properties of ethylcellulose it should be ideal to use in the type of lacquer desired for pencil finishing. To the author's knowledge there has not yet been any work done in this field therefore the following work is an attempt to indicate the uses of ethylcellulose in pencil finishes. 


\section{THEORETICAL}

The formulations for penoll laoquers is more or less standardized throughout the country. Half second nitrocellulose being the chief constituent of the vehicle. In itsolf it is very brittlo so it is necessary to add oils to make it more plastic and resins to give binding power and gloss. The thinners must be volatile enough to be thrown off in a vew seconds and there must be no solvent retention in the dried film. These lacquers dry solely by evaporation and there must bo enough nitrocellulose present to give a tack free film with the ofl and the resin. Therefore the formulation must be perfectly balanced in all these respects.

Materials available for this study were blown linse日d 011, blown soy-bean 011, and paranol, 4541 resin. These materials are somewhat now in the lacquer industry as far as penoll lacquers are concerned. of the two ofls mentioned, blown linserd seemed to glve the better properties. Ethylcollulose has a larger bulking value than nitrocellulose therefore it is possible to get a larger amount of cotton in the dried film. Since its plastic properties are much better than those of nitrocellulose it should be possible to decrease the amount of oil, plasticizer and resin in the final formulation. 
RAW MATERIALS

Ethylcellulose

Standard ethoxy grade 48.5-49.5 ethoxy; viscosity 7 C.P. as determined on an $80-20$ toluene (5\%) ethyl alcohol solution at $25^{\circ} \mathrm{C}$.

011

Solinox Z; a blown Linseed oil with a viscosity of about Z-6 on the Gardner Holdt soale.

Plasticizers.

Dibutylphthalate and Trioresylphosphate, standard

lacquer grado.

Hercules Powder Company.

Resins

Beokasol, 1324, 50\% solution in $\mathrm{Xyl}$.

Relchold Chemical Company

Paranol, 4541.

Paramet Chemical Company.

Pigments

Titanium dioxide, Titanox $R 610$.

Titanium Pigment Company

Chrome Yellow medium, no. 2283.

Chrome orange, no. 2810.

Kentucky Color and Chemical Company.

Iron Yellow, Lemon Yellow, no. 1149-L.

George S. Mepham Company.

Lithol Red, Lithol Red toner, no. 1033.

Kentucky Color and Chemical Company.

Multifex MM, a specially treated calcium carbonate matorial.

R.T. Vanderbilt Plgment Company.

Solvents

Ethyl alcohol, ethyl acetate, butyl alcohol, butyl acotate, isopropyl alcohol, and acotono, standard lacquer grado.

U.S. Industrial Chemical Inc. 


\section{P ROCEDU RE}

The pencil lacquers were prepared in the conventional manner. The pigments were first ground in the oil, resin and plasticizer on a standard throe roll paint mill to form a heavy paste. About threo passes wore necessary to obtain a smooth grind. The ethylcellulose was then dissolved in the solvents and the pigmented paste added to complete the lacquer.

The standard nitrocellulose lacquer formula shown in Table I was used as a basis for starting this investigation. Lacquers were prepared substituting ethylcellulose for the nitrocellulose. These lacquers proved to be too soft and did not dry vəry rapidly. The film was mushy and was not tack freo even after thirty minutes. The plasticizer and resins were then reduced in the precoding formulae until desired drying and film properties were produced. The thinner combinations were then adjusted to improve drying. This method was followed in both the clear and pigmented lacquers. The lacquer given in Table I is a typical poncil lacquer sold by a reliable manufacturer and it has given very good results over a Iong period of time. Due to wartime conditions some of the raw materials are new, but they have been found to be successful substitutes for the ones originaliy employed. The pigments used were representative of all types which may be encountered in pencil lacquer formulations. 


\section{TABLE I}

STANDARD NITROCELLULOSE IACQUER FORNULA

$\begin{array}{lc}\text { Material } & \text { Percent* } \\ \text { Chrome Yellow } & 16.22 \\ \text { Chrome Orange } & 4.95 \\ \text { Iron Yellow } & 1.67 \\ \text { Multifex } & 5.01 \\ \text { Beckasol 1324 } & \\ 50 \% \text { solutlon } & 7.88 \\ \text { Castor 01l } & 2.57 \\ \text { Dibutylphthalate } & 3.15 \\ \text { Ethyl Aloohol } & 9.64 \\ \text { Acetone } & 4.72 \\ \text { Butyl Alcohol } & 1.95 \\ \text { Butyl Acetste } & 3.13 \\ \text { Isopropyl Alcohol } & 7.01 \\ \text { l/2 sec. Nitrocellulose } & 32.10\end{array}$

* Percent by weight.

NOTE: Standard red and white pencil lacquers use the same vehicle combination. The only change in the formula being that the proper amounts of red and white pigments are added to give sufficient covering. 
To prepare the lacquers for testing, pencils were coated in a standard pencil coating machine under regular production condtions. They received from three to five costs and some recelved a clear top coat. The clear lacquer was also tested by itself.

\section{METHODS OF TESTING}

The properties desired in a pencil lacquer are: a hard tough film which will not go brittle in aging, a rapid tack free dry (about 30 seoonds) and a high covering power. The hardness is tested by cutting the film with the end of the finger nall and then examining the cut for cracks. The brittleness is tested in the same manner after about 36 months.

The tack free drying is tested by taking a hand full of the finished pencils, squeezing them together and then dropping them from a height of about 12 inches. If all the penc1ls completely separate, they are consldered tack free. The covering is determined by comparing the number of coats necessary to give complete covering with a standard pencil lacquer formula. 
RESULTS

The data and results obtained on the pencil lacquers prepared are given in the following tables. Lacquers made with white pigments are given in Table II, those containing red in Table III, and those containing yellow in Table IV, and the clear top coats are given in Table V.

The finished laoquers were tested according to the schedule listed under methods of testing, and then compared with a standard pencil lacquer. The results of these tests are also given in Table VI.

\section{TABLE II}

FORMULAE FOR WHITE PENCIL LACQUERS

$\begin{array}{lccc}\text { Pigment } & \begin{array}{c}\text { I } \\ \text { Percent* }\end{array} & \begin{array}{c}2 \\ \text { Percent }\end{array} & \begin{array}{c}3 \\ \text { Percent }\end{array} \\ \mathrm{TlO}_{2} & 15.59 & 16.23 & 16.81 \\ \text { Lithophone } & 4.74 & 4.94 & 5.11 \\ \text { Beckasol 1324 50\% } & 13.57 & 8.49 & 4.82 \\ \text { Silinox Z } & 4.10 & 2.82 & 3.37 \\ \text { Solvesso \#I } & --.- & 1.85 & 1.92 \\ \text { Isopropyl Alcohol } & 11.25 & 11.76 & 12.16 \\ \text { Butyl Acetate } & 2.44 & 2.54 & 2.62 \\ \text { Butyl Alcohol } & 4.50 & 4.66 & 4.82 \\ \text { Ethyl Acetate } & 11.46 & 11.93 & 12.36 \\ \text { Acetone } & 6.54 & 6.81 & 7.05 \\ \text { Ethylcellulose 7 c.p. } & 26.80 & 27.95 & 29.00 \\ \text { * Percent by weight. } & & & \end{array}$




\section{TABLE III}

FORMULAE FOR RED PENCIL IACQUERS

\begin{tabular}{|c|c|c|c|}
\hline Pigments & $\frac{1}{\text { Percent* }}$ & $\begin{array}{c}2 \\
\text { Percent }\end{array}$ & $\begin{array}{c}3 \\
\text { Percont }\end{array}$ \\
\hline Iithol Red Toner & 3.37 & 3.66 & 3.73 \\
\hline Chrome Orange & 6.03 & 6.54 & 6.68 \\
\hline Multifex** & 6.03 & 6.54 & 6.68 \\
\hline Bockasol $132450 \%$ & 14.81 & 10.60 & 10.90 \\
\hline Silinox $\mathrm{Z}$ & 4.04 & 2.93 & 2.99 \\
\hline Dibutylphthalato & 3.37 & 1.92 & $-\cdots$ \\
\hline Ethyl Aloohol & 11.12 & 12.20 & 12.32 \\
\hline Butyl Aloohol & 2.42 & 2.59 & 2.67 \\
\hline Butyl Acotate & 4.44 & 4.82 & 4.92 \\
\hline Ethyl Acetato & 11.52 & 12.32 & 12.58 \\
\hline Aćetone & 6.47 & 7.03 & 7.17 \\
\hline Ethylcellulose 70. & .26 .60 & 28.90 & 29.43 \\
\hline
\end{tabular}




\section{TABLE IV}

FORMULAE FOR YELLOW PENCIL LACQUERS

\begin{tabular}{|c|c|c|c|}
\hline Pigments & $\stackrel{1}{\text { Percont* }}$ & $\begin{array}{c}2 \\
\text { Peroent }\end{array}$ & $\begin{array}{c}3 \\
\text { Percent }\end{array}$ \\
\hline Chrome Fellow & 15.87 & 13.10 & 13.92 \\
\hline Chrome Orange & 4.84 & 3.96 & 4.25 \\
\hline Iron Yellow & 1.63 & 1.61 & 1.72 \\
\hline Multifex** & 5.88 & 5.79 & 6.22 \\
\hline Bookasol $132450 \%$ & 13.62 & 13.39 & 10.38 \\
\hline Solinox z & 6.79 & 6.69 & 6.02 \\
\hline Dibutylphthalate & 3.37 & 3.33 & $\cdots-$ \\
\hline Isopropyl Aloohol & 11.44 & 9.39 & 10.05 \\
\hline Butyl Acotate & 4.56 & 3.74 & 4.01 \\
\hline Butyl Alcohol & 2.48 & 2.03 & 2.18 \\
\hline Ethyl Aoetate & 11.68 & 9.57 & 10.25 \\
\hline Acetone & 7.97 & 5.46 & 7.02 \\
\hline Ethylcellulos 7 c.p. & $\cdots-$ & 22.08 & 24.10 \\
\hline Ethyloellulose 22 o.p. & 10.03 & $--\cdots$ & $-\cdots-$ \\
\hline
\end{tabular}

* Percent by welght. * Ppt. $\mathrm{CaCO}_{3}$. 
TABLE $V$

FORIULAE FOR CLEAR TOP COATS

$\begin{array}{lc}\text { Material } & \text { Percent* } \\ \text { Ethylcellulose } 7 \text { o.p. } & 50.40 \\ \text { Tri-Cresyl Phosphate } & 2.80 \\ \text { Lacquer Naphtha } & 7.48 \\ \text { Butyl Acetate } & 5.10 \\ \text { Butyl Alcohol } & 1.94 \\ \text { Ethyl Acetate } & 13.44 \\ \text { Ethyl Alcohol } & 9.22 \\ \text { Acetone } & 6.82 \\ \text { Paranol } 4544 & 7.80\end{array}$

* Percent by weight. 


\section{TABLE VI}

\section{RESULTS OF TESTS}

\begin{tabular}{|c|c|c|c|c|c|}
\hline Sample & $\begin{array}{l}\text { Tac } \\
\text { Tim }\end{array}$ & 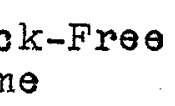 & $\begin{array}{l}\text { Hard- } \\
\text { ness }\end{array}$ & $\begin{array}{l}6 \text { Month } \\
\text { Age* }\end{array}$ & Remarks \\
\hline Red \#1 & 55 & sec. & soft & $0 . K$. & $\begin{array}{l}\text { Too much plasti- } \\
\text { cizer, slow dry, } \\
\text { mushy film. }\end{array}$ \\
\hline Red \#2 & 35 & sec. & medium & $0 . K$. & Good dry; good film \\
\hline Red \#3 & 30 & sec. & good & $0 . K$. & Good dry; good film \\
\hline Red. std. & 25 & seo. & good & $0 . K$. & $\begin{array}{l}\text { Std. Nitrocel- } \\
\text { lulose formula }\end{array}$ \\
\hline & 60 & sec. & soft & $0 . K$. & Too sopt; too long \\
\hline White \#2 & 30 & sec. & good & $0 . K$ & A good film \\
\hline White \#3 & 15 & $s \theta c$. & granular & $\rightarrow-r$ & Not very good. \\
\hline White std. & 20 & sec. & good & $0 . K$. & $\begin{array}{l}\text { Std. Nitrooel- } \\
\text { Iulose formulas. }\end{array}$ \\
\hline Yollow \#I & 50 & sec. & mushy & $\cdots$ & $\cdots$ \\
\hline Yellow \#2 & 50 & sec. & soft & --- & $-\cdots$ \\
\hline Yellow \#3 & 35 & sec. & good & $-\cdots$ & $\begin{array}{l}\text { Good film; good } \\
\text { drying time. }\end{array}$ \\
\hline Yellow sta. & 30 & sec. & geod & $0 . K$ & $\begin{array}{l}\text { Std. Nitro- } \\
\text { cellulose formulae. }\end{array}$ \\
\hline Clear & 30 & sec. & $\begin{array}{l}\text { very } \\
\text { good }\end{array}$ & $0 . K$. & Excollent film. \\
\hline Std. & 30 & sec. & good & $0 . K$ & $\begin{array}{l}\text { Std. Nitrocel- } \\
\text { lulose formulae. }\end{array}$ \\
\hline
\end{tabular}

NOTE: 3 coats gave sufficient covering with the exception of white \#1, 5 coats being necessary in this case. For the clear coat only one coat was used.

* Test for brittleness. 


\section{CONCLUSIONS}

From the tests on the drying and film properties of the ethylcellulose pencil lacquers we may conclude that when proper balance of solvents, plasticizers, oils, and resins are used we can successfully make good pencli lacquers. In the comparison with the nitrocellulose lacquers some of these ethylcellulose lacquers may be considered as good as the former. The clear top coating la cquer worked exceptionally welliand probably will be used for this purpose in the future whenever price permits.

\section{REC OMMENDATIONS}

The work indicates that it is highly possible that suitable pencil lacquers may be made from ethylcellulose. Therefore an investigation of other oils and resins would be adviseable as soon as they are again commercially available. Some other resins and olls would probably be more suitable. Possibilities are blown castor oil, blown synthetic oils of the malalc acid type and non drying resins suoh as Paraplex R.G. 2, Paraplex G20, and Duraplex N.D. 75. It might also be adviseable to use demar gum in the olear finishes.

A better combination of thinners might also be found since ethylcellulose has a wider range of solubility than the nitrocellulose. 
ACKNOWLEDGMENTS

The Author wishes to express his sincere appreciation to the Dow Chemical Company for making this work possible.

He is also very grateful and expresses bis sincere thanks to Mr. Otto J. Mileti of the Charles R. Long Jr. Paint Company for his splendid suggestions and recommendations, and to Mr. A. E. Young of the Dow Chomical Company for his cooperation in this work. 


$$
V I T A
$$

Albert Louis Kimmel was born in Louisville, Kentucky on April 2, 1917, the son of Albert J. and Iouise Bromm Kimmel. He received his primary education at $s t$. Joseph's Parochial Schocl, his High school education at St; Xavier High School and his college work at the University of Louisville. He received his Bachelor"s Degree in lhemical Lngineering in June 1940. In september 1940, he entered the Night Graduate School of the University of Louisville and in September 1941 received the Dow Fellowship. He received his lvaster's Degree in Chemical Engineering in February 1945.

After completion of his undergraduate work in Chemical ingineering he was employed by the Charles R. Long Jr. Paint Company in Louisville, Kentucky and is in their employ at the rresent time. Ifr. Kimmel is a Junior member of the A.I.Ch. F and a member of the American uhemical society.

Ehile an undergraduate student he participated in intramural athletics, was a member of the Neman Club and a student member of the A.I.Ch. ․ 